\title{
Jesus Lives in Me: Pentecostal Conversions, Witchcraft Confessions, and Gendered Power in the Trobriand Islands
}

\author{
Michelle MacCarthy
}

\section{INTRODUCTION}

In August 2013, I attended a Revival Crusade in the Trobriand village of Omarakana. Pastors from various Pentecostal and evangelical churches had been invited from southern Kiriwina and the outer islands to preach, testify, and perform alter calls to engage the holy spirit and effect conversions for those ready to be born again. While these male pastors who were generally the figures leading prayers and alter calls were charismatic and compelling, what interested me most of all were the conversations I had on the periphery of these proceedings, mostly with women from the southern Kiriwina village of Sinaketa. Several of these women, including a pastor's wife named Esther, told me that they were witches, but that they had now been kalobusivan (born again) in the Pentecostal faith, and had renounced their past misdeeds. After living for nearly two years on the island, I had had it firmly instilled in me that no one, ever, would openly

\footnotetext{
M. MacCarthy $(\bowtie)$

Department of Anthropology, Saint Mary's University, Halifax, Canada

(C) The Author(s) 2017

K. Rio et al. (eds.), Pentecostalism and Witchcraft, Contemporary Anthropology of Religion, DOI 10.1007/978-3-319-56068-7_6
} 
admit to being, or having been, a witch. Accusations might be made in hushed tones amongst close kin or friends, but never spoken publically, and there are no public or violent reprisals against known witches, unlike in other parts of PNG and Melanesia. How was it that Pentecostal Christianity had made it possible not only to proclaim to both friends and strangers that one is, or has been, a witch, and what does this mean for women's agency and power? How are these various forms of power embodied, and as embodied power, how can a witch denounce that which is physically a part of herself? What is the particular power of Revival Christianity that can disembody the embodied? These questions pressed me to think about gender, Pentecostal Christianity, and witchcraft in my own case study, and to understand these phenomena in a comparative perspective.

\section{WitchCraft AND SORCERY In COMPARISON: The Massim and Beyond}

Massim witchcraft and sorcery are of course well-documented and amply represented in the anthropological corpus. Malinowski had much to say on the topic of magic in both its malevolent and beneficent forms, and his work was shortly followed upon by Reo Fortune in his classic treatise, Sorcerers of Dobu (1932). Since then, Stanley Tambiah, Susanne Kuehling, Martha Macintyre, Mark Mosko, and Nancy Munn, among others, have had much to add to our understanding of magic, sorcery, and witchcraft as they are variably practiced and understood in this anthropologically rich region. PNG, and Melanesia as a whole, are known to host a variety of occult forms, and has often been contrasted with Africa in this respect; for example, Marwick made the distinction in 1964 between Africa's "witches" as insiders and Melanesia's "sorcerers" as outsiders (1964), a dichotomy that has since, not surprisingly, been shown to be far too neat to reflect reality. Geschiere (2013) has also taken up this comparison, as we do in this set of papers.

In the Trobriands, a variety of occult forms is locally recognized. The vernacular term meguwa is usually translated as magic, a generic term that denotes any kind of manipulation of phenomena to effect a desired outcome, positive or negative, though it most generally refers to benevolent (or at least, not evil) forms of magic such as love magic, beauty magic, healing magic, garden magic, or weather magic (though these may also have more specific terms). These are for the most part (with the exception of weather magic) democratic, unspecialized forms of magic, which do not require elite or chiefly status, particular specialization, or unique qualities to perform. Usually effected through spells, charms, the 
observance of taboos, and so on, the incantations and associated actions can be learned, usually taught by an elder relative and usually requiring some form of payment. Those whose skill in performing particular kinds of magic are well-known are sometimes solicited for help in performing magic on someone else's behalf, and again this normally requires some kind of payment in the form of valuable wealth items like pigs, shell valuables, stone axe blades, clay pots, and/or cash.

Trobrianders also distinguish between bwagan and yoyowa, two forms of supernatural and largely negative magical power which they consistently translate into English as sorcery and witchcraft respectively. Bwagau and yoyowa create a great deal of fear, unrest, and suspicion, especially in the context of sickness or death, as these are inevitably construed as the result of malevolent action (usually due to jealousy, anger, or resentment) on the part of a sorcerer or witch. Local conceptions of the supernatural power of witches, on the one hand, and sorcerers, on the other, largely fall in line with Evans-Pritchard's classic descriptions (1937). That is to say, "a witch performs no rite, utters no spell, and possesses no medicines. An act of witchcraft is a psychic act...sorcerers may do...ill by performing magic rites with bad medicines", which, in the Trobriands case, often means natural or chemical poisons (Evans-Pritchard 1937: 1). Furthermore, as we shall see from the ethnographic case of the Trobriands, witchcraft is considered (as it is for the Azande) to be in and of the body (Evans-Pritchard 1937: $3)$. Witchcraft resides as a sort of substance, or perhaps essence, in the body, and yet acts of witchcraft are performed while the witch is disembodied; a Trobriand witch performs evil acts as a spirit which leaves the physical body of the witch while she sleeps; while the spirit is absent, the body is at great risk, as any disturbance to the sleeping shell will mean sickness or even death to the witch. Conversely, sorcerers perform their malevolent acts by physically moving around at night, under cover of darkness, to perform rites, give bespelled or even poisoned comestible items to victims, and particularly strong sorcery is often related to chiefly rank.

Malinowski (1929) describes the differences between bwagau on the one hand, and yoyowa or mulukwausi ${ }^{1}$ on the other:

Although by far the most important of them all, the bwaga' $u$ is only one among the beings who can cause disease and death. The often-mentioned flying-witches, who come always from the Southern half of the island, or from the East, from the islands of Kitava, Iwa, Gawa, or Murua, are even 
more deadly. All very rapid and violent diseases, more especially such as show no direct, perceptible symptoms, are attributed to the mulukwausi, as they are called. Invisible, they fly through the air, and perch on trees, house-tops, and other high places. From there, they pounce upon a man or woman and remove and hide "the inside," that is, the lungs, heart and guts, or the brains and tongue. Such a victim will die within a day or two, unless another witch, called for the purpose and well paid, goes in search of and restores the missing "inside." (Malinowski 1929: 76)

\section{Malevolent Places, Bodies, and Metaphysics}

As Malinowski alludes, there is a certain geographical division between the domains of sorcerers and witches, though these are by no means mutually exclusive. In the northern regions of Kiriwina Island, sorcerers dominate. This is, not coincidentally I think, the ancestral homeland of the highest-ranking of the Trobriand matriclans, including the Tabalu clan, to which the Paramount Chief of the islands must belong. The long-standing seat of chiefly power, Omarakana Village, is where the Trobriand Paramount Chief resides and is also home to stones that only he can manipulate to bring rains or drought as he sees fit. In the south, as well as in the smaller outer islands of the Trobriand group-the areas to which the chiefs and leaders of the northern district travel by kula canoe to exchange valuables, often across dangerous seas-is where witches predominate. My own fieldwork was mostly carried out in the village of Yalumgwa, in the north, the domain of sorcerers. While I was sometimes told that my adoptive father had to be careful to avoid being poisoned by sorcerers, as his own father was purported to be, I was not led to believe that I had anything to fear. Mata's father had been sorcelled because of his own ambition; he had built a yam house, though he was not himself a chief, and this was seen by the rightful chiefs of the village as subordinate and a challenge to their authority, according to my adoptive mother. Mata kept his own ambitions far less lofty, to avoid a similar fate. And if sorcerers were something to be aware of, they were inevitably amongst us, and we simply had to manage the risk. Whenever I traveled to the south or the outer islands, however-that is, to the domain of witches, the "other" of potentially evil supernatural forces (or perhaps the "other same", as suggested in the introduction to this volume)-my adoptive mother gave me lengthy lectures about how to behave, to ensure that I did not inadvertently upset a witch, and bring sickness or death to me or to the family who cared for me. Should 
a woman there compliment me on my clothing, string bag, jewelry, or anything else, I was not to hesitate, but to give it away immediately. Even such a small thing as failing to give a betel nut to a witch could potentially result in retribution. There were plenty of stories to be recalled and retold about the sorts of things witches could do and had done. While to be sure, there were a few witches living in our own villages, it was those witches, in those villages, who were truly to be feared. Witches in this context are both inside (relatives, in neighboring villages) and outside (not-exactly-us-but-those-people). They are the outside threat that is also intimate and internal, as argued in the introduction to this volume.

There is also a gendered distinction. While men can be witches and women can be sorcerers, these are symbolically gendered categories. In practice, the majority of sorcerers are men, and witches predominantly (but by no means exclusively) women, though my Trobriand interlocutors were adamant that the gendered categories were not absolute. This may be an example of what Sanders (2008: 161) refers to as a performance of gender, in which gendered ideals are performed or enacted irrespective of men's and women's sexed bodies. To return again to Malinowski, he states it thus:

The magic of illness and health, which can poison life or restore its natural sweetness, and which holds death as it were for its last card, can be made by men and women alike; but its character changes entirely with the sex of the practitioner. Man and woman each have their own sorcery, carried on by means of different rites and formulae, acting in a different manner in the victim's body and surrounded by an altogether different atmosphere of belief. (1929: 45)

Fortune also paints a stark contrast in gendered forms of supernatural power, though he (like Malinowski) clearly makes gendered divisions absolute and tied to sexed bodies:

Witchcraft is the woman's prerogative, sorcery the man's. A witch does all of her work in spirit form while her body sleeps, but only at the bidding of the fully conscious and fully awake woman and as the result of her spells, it is said. Not only is all that we term accident as opposed to sickness ascribed exclusively to witchcraft, but a particular way of causing illness and death is the monopoly of women. This method is that of spirit abstraction from the victim. The man, as sorcerer, has the monopoly of causing sickness and death by using spells on the personal leavings of the victim. (Fortune 1963: 150) 
This is perhaps more a product of the era in which it was written and the more dichotomous, less nuanced view of gender prevalent at the time of Fortune's research, rather than a reflection of the emic point of view of who can and does practice witchcraft and sorcery.

\section{Equivalence AND INFLUENCE}

Despite hierarchies of chiefs, headmen, and ranked sub-clans, individuals are accorded significant autonomy in all social relationships (Weiner 1976: 212). Weiner stresses that in the Trobriands,

[T]here exists a strong ethic of equivalence, despite rank and other status differentiations. People are not free to command each other. They cannot effect their will over another person. But Trobrianders believe that it is possible to influence the disposition of others. Such influence, however, has limitations, and the process is notoriously fallible. (Weiner 1976: 212; italics in original)

Such influence is achieved through two primary means: gifts and the use of magic. The latter might further be subdivided into the kinds of benevolent magic or meguwa as described above, and the two malevolent forms of supernatural power, bwagau (sorcery) and yoyowa (witchcraft). Gifts and their reciprocation are the basis of all functional relationships in the Trobriands; between kin, affines, friends, lovers, marriage partners, business partners, and so on. Indeed, many are the Trobrianders who complain, especially in a place where money is scarce and hard to come by, about the heavy burdens of exchange obligations. Witches, in many ways, reinforce the moral obligation to share what one has. Pogi (in the vernacular) or jelas (in Tok Pisin), meaning jealousy or envy is the usual cause of a witch's wrath, so giving freely and thus meeting and exceeding all expectations for exchange obligations (with close and further kin and with those from outside one's own community and family) is the only surefire way to protect oneself from becoming ill or unwell at the hands of a witch's actions (see also Strong, Pype, and Stroeken's contributions to this volume). Indeed, the primary reason given why a witch would cause trouble and bring illness or death to someone is always considered to be that she is, for one reason or another, jealous, envious, or covetous. The relationship between jelas and witchcraft and/or sorcery is well established in this contemporary Melanesian context (Bratrud, this 
volume; Rio 2010; Eves and Forsyth 2015; Taylor 2015). Related to this is the point that envy is an idiom of egalitarianism. Nancy Munn (1986) has similarly argued that Gawan society is characterized by an egalitarian ethos, as does Lepowski based on her fieldwork in Vanatinai (1993). The witch is simultaneously a personification of dominion and radical superordination that negates equalization and balance in intersubjective relations; and at the same time, she emerges punitively in contexts where an imbalance appears to violate this ethic of egalitarianism (Munn 1986: 233). The witch, Munn tells us, "operates to enforce the principle that any increment accruing to one or more persons over and above what others have is subject to another's claim" (1986: 233). She suggests that the contradiction can be reconciled by understanding Gawans' experience with individualistic egalitarianism in their society as domination, a domination personified in the witch. Munn also identifies the intrinsic hiddenness of another's views/intentions/thoughts: "we do not know his/her mind" (Gala tanukwalisi matona/minana lananamsa). Pretense and deception (katudewa) are always possibilities, and this is particularly potent when the underlying threat of deception includes violence or illness wrought by witchcraft or sorcery. This holds as true for Kiriwina and in the discourses of my interlocutors as Munn describes for Gawa in the 1970s. The extent to which such a looming threat actually affects equivalence or redistribution is debated, however; Taylor (2015: 48), for example, argues that the jealousy of witchcraft only reinforces existing political and socio-economic inequalities, perhaps exacerbating rather than mitigating them.

Power is a significant concept here, and should not be glossed over. As Zelenietz (1981: 5) pointed out, the use of sorcery and witchcraft are expressions of a desire to control both one's own fate and the destiny of others. But it is not only available to those in socially recognized positions of authority, such as chiefs. Those in the margins may also exercise this form of power, and Zelenietz suggests that "sorcery and witchcraft assume their most terrifying aspects when used by peripheral members of society to assert control over destiny, to redress what they perceive as wrongs or imbalances in society" (1981: 5). This is perhaps the case with acts of sorcery carried out by children or adolescents, or witchcraft by women of commoner status (compare also the role of children with the gift of discernment, as described by Bratrud in this volume). This notion of sorcery being most fearsome when carried out by marginal or dispossessed individuals as a means of challenging the existing social order is 
well established in the African literature (see, for example, Badstuebner 2003; Comaroff and Comaroff 1993; Moore and Sanders 2001; Nadel 1952), but perhaps less explicitly so in Melanesia.

\section{What Makes a Witch a Witch \\ AND A SORCERER A SORCERER?}

It should be noted that even within Melanesia, as well as in comparative African contexts, the distinction between what I here describe as sorcery and witchcraft are not so distinct. Indeed, in some cases, these terms seem to be used interchangeably, as they do not seem to fit the "classic" definitions. However, as mentioned at the outset of this paper, in the Trobriands case there is surprising accordance with Evans-Pritchards' descriptions, according to the ways in which my interlocutors described each of these forms of malevolent power. In both the comparative literature I cite here, and in the other contributions to this volume, it is important to distinguish just what is meant by the selection of and use of one or the other of these terms.

Stephen (1987) attempts also to distinguish witches from sorcerers, based on a variety of ethnographic examples from various societies in PNG. She shows a great diversity in manifestations of both sorcery and witchcraft, again demonstrating that the insider/outsider binary is insufficient to capture the complexity of ethnographic reality. She rather asserts that the key difference between the two is in the social roles their practitioners hold: sorcerers use destructive mystical power to gain social influence, while witches are outcasts whose actions lead to social ruin (Stephen 1987: 288). However, she acknowledges that the southern Massim, including the Trobriand Islands and Dobu, are exceptions to her argument, thereby leading her to suggest that Trobriand witches are better described as female sorcerers (1987: 286). While this certainly helps to make her distinctions more applicable, there are difficulties with her argument. She suggests that:

Melanesian societies usually draw sharp distinctions between male and female roles and spheres of action; it is thus only to be expected that female sorcery will differ from male sorcery. Given the general association in Melanesia of masculinity with order and control, it is appropriate that female sorcery should be less deliberate and less fully controlled than male 
powers, and that it will be symbolized by the destructive aspects of femininity. (Stephen 1987: 286)

Her assertion of a "sharp distinction" between gender roles and actions becomes less compelling in the face of the insistence of Trobrianders that witchcraft is, in fact, not the exclusive domain of women; they point to male witches, and they are no more socially outcast than female witches (though, so far as I know, they are not chiefs or leaders in their communities). What is more, the argument that sorcerers are powerful members of society also does not hold for the Trobriand case, where people complain that today, even young people are practicing sorcery. That said, it is most often powerful men (chiefs and other leaders) who have a reputation for the most fearsome sorcery.

The Trobriand witches I spoke to at the Revival meeting were neither prominent figures nor were they dispossessed or marginalized. They were, like most other Trobriand women, mothers, wives, daughters, and aunties; diligent gardeners; and faithful members of their church congregation. Indeed, on the last count, they were more devout than many. They had traveled from significant distances to attend the rally, both for their own spiritual development, and to support their husbands (many of the women were in fact married to church leaders). It is significant, I think, that the Pentecostal and Pentecostal-like churches in the Trobriands are notably different from the so-called "mainline" or long-established churches there-namely, Catholic, un-revived United, and Seventh Day Adventist churches - especially in their inclusion of women as lay preachers, song leaders, and musicians (usually playing the tambourine) in church services; in the "mainline" churches, women generally have little voice outside of their designated Women's Fellowship meetings once a week. Women like Esther and her friends not only often have the opportunity to lead or speak for portions of a church service or Revival meeting (though this one was still dominated by male speakers), but they also conduct "open-air" singalongs and services in the government station of Losuia $^{2}$. Their devotion and adherence to a life filled with the Holy Spirit and their stress on the importance of their spiritual rebirth was, at least in part, framed as a contrast to their identification as reformed witches. This contrast served to reinforce the psychological and material importance of being born again, and the spiritual challenges they faced as a result of the egregious acts they had committed before finding their place in the faith. 


\section{Fear and Loathing: The Trobriand Witch and Pentecostal Redemption}

People described to me the fearful visage of the witch, leering down from the rooftop. She has bulging eyes, a huge, gaping mouth with dagger-like teeth, and snot streaming from her elongated nose. Her ears are also disproportionately large, and she has long white hair. When her victim screams upon sighting her, she will place a "picture" of the coveted item which has aroused her jealousy in the victim's stomach, as people described it to me. This item, out of its proper place, invades the body and causes illness. Alternatively, the witch might "bite" the victim, creating a painful open sore. Biomedicine cannot heal these kinds of sicknesses, Trobrianders contend; they can only be treated with counter-magic.

The southern village of Sinaketa has long had a reputation for the power of its witches, but today this village is also a stronghold of Pentecostal worship in the Trobriands, which arrived in Kiriwina about 25 years ago, following a 100 years of missionization by Methodists and Catholics. While there is still a United Church in Sinaketa, as with many other United Churches the arrival of a Pentecostal denomination, in this case the CRC Church (Christian Revival Crusade), not only sees people converting to the new faith to worship in the CRC congregation, but also instigates a "Pentecostalization" or Revival movement within longer established churches. Some women in Sinaketa, and especially those who have been born again in the Pentecostal faith, confess that they are witches, in itself a departure from the customary taboo on such a public acknowledgment. However, they claim that as born again Christians, they have to pray away the evil that resides within them and would otherwise compel them to behave immorally. Women speak of how both witchcraft and Pentecostal forms of Christian belief reside olumolela, or "inside", usually described as situated olopola, in the stomach. This topic isn't necessarily spoken about in the context of highly public testimonials, but can just as easily occur in casual conversations, as I found out when chatting to some women from Sinaketa on the periphery of the dramatic and charismatic preaching of the Crusade. This is not a case like Badstuebner (2003) describes in South Africa, in which women use "risky agency" to negotiate gender violence and dislocation; nor is it like Pype's (2011) description of public confessions accompanied by spiritual cleansing rituals in Kinshasa. 
In fact, the women acted surprisingly blasé about their conversions, using them only to illustrate just how significant they felt their spiritual rebirth to be.

Esther is the wife of a CRC pastor in the southern village of Sinaketa. I met Esther and some of her friends at the island-wide Pentecostal "Revival" crusade I mentioned in the opening of this paper. As I sat in the grass with this group of women, they spoke about their conversions to the Pentecostal faith. I was shocked when Esther told me she was a witch. With no hesitation, she told me how her father, who was also a witch, had instructed her when she was small. She was taught not to use certain objects which signify a woman's expected domesticity, like brooms and coconut husks, as these were $t a b u^{3}$ to witches. She explained how her double would leave her own body as she slept, how her eyes and ears would grow large and grotesque, how she brought sickness and death to those who she felt had wronged her. She would then return to her own sleeping body to reinhabit it, fully aware of the things she had done, but would resume her business in the village the following day without the slightest ill conscience for what she had done. However, when the CRC church came to Sinaketa, and people joined it in high numbers, Esther told me that she saw people "living well" in the church. She came to know the power in prayers of confession, and she was born again: besatuta navau yegu, she told me-now, I am a new woman. Jesu isisu olumwolela-Jesus lives in me, she insisted, such that the hidden spirit or power of the yoyowa is overpowered. With the deliverance, as she put it, gained through prayer and confession of past misdeeds, she "felt free". While it was an ongoing battle to ensure that she did not revert to her old ways, the power of her faith was strong. She said that this was a bit easier for her than for many of the other reformed witches in Sinaketa, however, because she had learned how to be a witch from her father. That is to say, it was given from a member of another matriline, and thus is not her tukwa, which could perhaps be translated as "ancestral heritage".

"True" witches, then, have a much harder time to replace the tukwa, an essential part of their physical being, with the power of Jesus. The acts of yoyowa are frequent topics of discussion in the village. My adoptive parents pointed out, as we sat chatting on the veranda one evening, that these women in the south, even when they claim to tapwaroru (pray, attend church, live a Christian life), they still can't help being witches because it comes from their clan members. 
When a witch commits an evil act, she is not really responsible for it. Witches do bad things pela ositukwa-because it is their ancestral heritage, and because this power is a part of them, a part of their very substance.

A woman I will call Kadubulula explained to me how this is the case. Kadubulula is from one of several southern villages known to be home to many witches. My close interlocutors told me that she was a well-known witch, and she had not been born again. She nominally worshiped in the United Church, but she was still a practicing yoyowa, and thus it might be tricky to talk to her. I could not, nor would she, make any reference to the fact that she is a witch; the interview was organized on the pretext that because she was from a village known to host many of them, she would know a thing or two about witches. We would have to conduct the interview while most people were off in the gardens, or Kadubulula might feel shy to talk about these things. If one can have an aura of yoy$o w a$, this woman certainly had it. She described for me how a yoyowa will pass the knowledge she holds to her daughter (and, indeed, the tukwa usually passes from mother to daughter). While the girl is still very small, perhaps just old enough to walk, the two will go together deep into the bush. There, they will both remove their clothes, and the mother will crouch down and open her mouth "as big as a door", as Kadubulula put it. The mother will swallow her daughter, and the young girl will reemerge through her mother's anus. From this moment, the girl will have all of the knowledge as well as the essential substance, so to speak, of the yoyowa, though she will continue to train and to further develop her powers.

When a woman is a yoyowa because it is her tukwa, it becomes harder for her to fully separate herself from this power, which she carries inside her, in her belly: the seat of emotions and understanding, memory, and the storehouse of magic (Tambiah 1983: 179). As Tambiah (1983: 175 ) points out, women not only reproduce the dala or matrilieage through giving birth, but are seen to transmit the dala identity or essence "which she carries inside her as part of her very constitution". The process of passing on tukwa, again following Tambiah, might be seen as an inversion of the (no longer salient) Trobriand belief that conception occurs when a spirit or baloma from a woman's deceased ancestor enters her body through her head (Malinowski 1929: 173, 175 ) and later emerges from her vagina, again being born physically imbued with the essence of the matriclan. There are other inversions; as 
Munn (1986: 219) notes, "[Witches] violate ordinary bodily spacetime in flying, a capacity that conveys a radical expansion of spaciotemporal control". They also shapeshift; for example, taking on the shape of a flying fox, a shark, or a falling star. And despite being passed primarily within a matrilineage, members of that same matrilineage are also the rightful targets of a given witch's attacks, according to my Trobriand interlocutors (see also Strong, this volume). The intimate connection between witches and their victims has also, of course, been observed by Geschiere (2013). What is more, witches feed on corpses (compare the body-snatching in Myhre, this volume). In this way, "rather than giving food to others to eat, the witch converts others into food, thus destroying the self-other relation." In this way, as Munn observes, she destroys relationality (1986: 227). In the African context, witchcraft has been described by Geischere as a betrayal of kinship (2003: 47), which just as well applies in the cases described here in the Milne Bay region of Papua New Guinea.

The embodied capacity of yoyowa, and the belly or stomach as its locus, is symbolized in other ways, too. Munn (1986: 221) observed that witches in Gawa are seen as hungry and greedy, and it is greed or jealousy (emotions which also resides in the belly) that generally compels witches to commit acts of violence against a victim. Again, from Munn:

Gawans say that when witches see that another person has something the witches themselves lack, they hate (-kamiriwey) that person and desire these things for themselves. The witch is jealous (-pogi); the stomach becomes angry (-kapasala nuwu-ra); the mind is made bad (-yageiga nano-ra), or the forehead made heavy (mwaw daba-ra) from seeing that others have more than oneself. (221)

Here, we can see echoes of the claim made in the introduction of this book that "envy in a fundamental way articulates the crucial claim to equality that is fundamental to both consumerism and to the relation between persons and God" (p. 22), as well as fundamental to Trobriand sociality. Perhaps Pentecostalism is in a way a more productive (in the emic view) means of accessing what Englund calls the radical promise of equality inherent in such a practice of Christian fellowship than the destructive, consumptive, and threatening power of the witch (Englund 2003). 


\section{CONCLUSIONS}

When a self-confessed witch is born again into a Revival church, there is a fundamental shift. Now, instead of the power and knowledge of witchcraft residing inside the body, that "space", so to speak, should be filled up by Jesus and the power of the holy spirit. This means relinquishing the power that comes with being a witch-the power to intimidate, and to exact revenge. Now, women such as Esther have only the power of prayer to affect the results they hope for. And, instead of being both the product of, and a potential threat to, one's extended kin network and especially one's own matriclan, now one's responsibilities are to the church community and to one's own nuclear family. As I have described elsewhere, the move to Revival forms of Christianity in many respects reorients the focus from spatially and temporally wide-ranging kin obligations to, instead, the household level, especially in the context of redistributive mortuary feasts (MacCarthy, In press). In the Pentecostal context, the dala or matrilineal kin, and the obligations for material reciprocity and redistribution entailed in maintaining those relationships, lose importance.

For witches, transcending the body (i.e., by flying at night in disembodied form) is key to their power. In the Pentecostal Christian context, as Eriksen has argued (Eriksen 2016), the ideal is conversely containment of the woman's body. In her study of Pentecostal women in Port Vila, Eriksen notes constraints of mobility and the need to always cover oneself-with clothing, inside the house or the church, etc.-behavioral changes that are seen as necessary in an urban Christian context. While women's physical movement in the Trobriands is not so constrained, the idea of containing femininity within the body offers a potentially useful analytical framework. No more can the spirit leave the body to parody femininity by wreaking havoc on the village; no more should the physical features expand grotesquely, with the exaggerated facial features that are said to characterize the witch; no more should mothers ingest their daughters and pass them through their own bodies, to be expelled pregnant with the skills and power of the yoyowa. Instead, good Pentecostal women should dress conservatively, do physical work to feed and care for their children and husbands, implying exactly the broom and the coconut husk so taboo to witches, pray and worship inside the church, and submit to the authority of God.

If witchcraft is inherently anti-social, by corrupting kinship obligations and inverting or subverting social rules, and transgressing the body in dangerous ways, then Pentecostal Christianity perhaps offers a new 
paradigm which reigns in kinship obligations, creates new social rules, and contains femininity within the body. As Schram (2010) has argued for neighboring Normanby Island, Christianity reshapes cultural conceptions of personhood, space, and time, and provides an epistemic frame in which witchcraft is always perceived as a survival of the past in the present (Schram 2010: 727). In the Trobriands, Pentecostal Christian discourse advocates breaking with the past (Meyer 1998). Pastors preach in Trobriand services about how culture or the old ways (gulagula) can be destructive and turn people away from God. They stress the need to give up many aspects of "traditional" Trobriand practice and belief in which unfettered female power is displayed; for example, performing Trobriand dances in traditional dress (wherein women expose their bodies in sexually suggestive performances), and the distribution of socalled "women's wealth", the banana leaf bundles women manufacture and distribute in the wake of the death of a kinsperson, and which are deemed "useless" and "unproductive" in Pentecostal discourses, as I have written about elsewhere (MacCarthy, In press). In such discourses, acts of witchcraft or sorcery are unequivocally evil and must be countered. Others (e.g., Geschiere 2013) have noted that Pentecostalism stresses a stark distinction between good and evil, though many of my informants, from all denominations, point to ambiguities and ambivalences. Nonetheless, to be properly Christian is to be modern, to follow Biblical teachings, and to turn away from past practices that are seen to contradict the word of God. Following the claims of many scholars, especially in Africa, that witchcraft is a thoroughly modern phenomenon (Geschiere 1997), it is also in the Trobriands recast inside a modernist discourse where witchcraft comes to stands for old, pre- and anti-Christian and unproductive behavior. For women like Esther, denouncing the evil living inside her belly can only be done if Jesus moves into that same space, such that good might overpower evil, and modernity and its associates (prosperity, development, enlightenment) might overcome tradition and the so-called "darkness" it instantiates in local discourses, and wherein tapwaroru stands as antidote and antithesis of witchcraft and sorcery. Indeed, the physical body is literally transformed in the process of being born again, replacing the dark powers gained from the previous "rebirth" when a young woman receives her tukwa from her mother. With Jesus filling up the space formerly inhabited by dark powers, perhaps these reformed witches can now find "deliverance" in a 
new community of openness, collective prayer and worship, and a focus on the nuclear family and church congregation-a new social space for women based on their shared transformation and a voice within the Pentecostal sphere which was hitherto limited to dark, solitary, destructive, and anti-social activities. The reformed witch comes to represent then a "new woman", as Esther described herself, not only on level of personal moral and spiritual transformation, but also as a reflection of a village, community, island, and even nation that needs to be reborn in order to move forward in a world where development seems to be lagging and poverty and sickness are still pervasive.

\section{Notes}

1. Malinowski often refers to mulukwausi, which he uses to refer to the disembodied second self of the yoyowa or witch, but my informants just used yoyowa to refer to both forms; indeed, as a verb, yoyowa means "to fly".

2. These events usually include a group of women numbering perhaps 10-20, who dress in matching calico clothes and travel together to the government station of Losuia with a portable PA system to preach, sing, play music, and perform short skits. On the day I joined them, in August 2013, it was a "combined fellowship" group from Pentecostal congregations from across Kiriwina, but with a good number coming from the village of Sinaketa.

3. The term tabu has generated much anthropological debate (Weiner 1976: 39). It means founding members of each matriclan, ancestors in general, grandparent, grandchild, father's sister, father's sister's daughter and other female relatives on one's father's side, and finally, it can also mean "taboo" or forbidden, as Esther used the term in this case.

\section{REFERENCES}

Badstuebner, Jennifer. 2003. "Drinking the Hot Blood of Humans": Witchcraft Confessions in a South African Pentecostal Church. Anthropology and Humanism 28 (1): 8-22.

Comaroff, Jean, and John L. Comaroff, eds. 1993. Modernity and Its Malcontents: Ritual and Power in Postcolonial Africa. Chicago: University of Chicago Press.

Englund, Harri. 2003. 'Christian Independency and Global Membership: Pentecostal Extraversions in Malawi'. Journal of Religion in Africa 33 (1): 83-111.

Eriksen, Annelin. 2016. "The Virtuous Woman and the Holy Nation: Femininity in the Context of Pentecostal Christianity in Vanuatu". The Australian Journal of Anthropology 27 (2): 260-275.

Evans-Pritchard, E.E. 1937. Witchcraft, Oracles and Magic Among the Azande. Oxford: Clarendon Press. 
Eves, Richard, and Miranda Forsyth. 2015. "Developing Insecurity: Sorcery, Witchcraft and Melanesian Economic Development". Vol. SSGM Discussion Paper 2015/7. Canberra: Australian National University.

Fortune, Reo. 1932. Sorcerers of Dobu: The Social Anthropology of the Dobu Islanders of the Western Pacific. London: G. Routledge \& Sons.

Fortune, Reo. 1963. Sorcerers of Dobu: The social anthropology of the Dobu Islanders of the Western Pacific. New York : E.P. Dutton \& Co.

Geschiere, Peter. 1997. The Modernity of Witchcraft. Politics and the Occult in Postcolonial Africa. Charlottesville: University of Virginia Press.

Geschiere, Peter. 2013. Witchcraft, Intimacy and Trust: Africa in Comparison. Chicago: University of Chicago Press.

Lepowski, Maria. 1993. Fruit of the Motherland: Gender in an Egalitarian Society. New York: Columbia University Press.

MacCarthy, Michelle. In press. "Doing Away with Doba? Women's Wealth and Shifting Values in Trobriand Mortuary Distributions". In Sinuous Objects: Revaluing Women's Wealth in the Contemporary Pacific, ed. A.-K. Hermkens and K. Lepani. Canberra: ANU Press.

Malinowski, Bronislaw. 1929. The Sexual Life of Savages in North-Western Melanesia. London: Routledge \& Kegan Paul.

Marwick, Max. 1964. "Witchcraft as a Social Strain-gauge". Australian Journal of Science 26: 263-268.

Meyer, Birgit. 1998. "Make a Complete Break with the Past'. Memory and Post-Colonial Modernity in Ghanaian Pentecostalist Discourse". Journal of Religion in Africa 28 (3): 316-349.

Moore, Henrietta, and Todd Sanders, eds. 2001. Magical Interpretations, Material Realities: Modernity, Witchcraft and the Occult in Postcolonial Africa. London: Routledge.

Munn, Nancy. 1986. The fame of Gawa: A symbolic study of value transformation in a Massim (Papua New Guinea) society. Cambridge: Cambridge University Press.

Nadel, S.F. 1952. "Witchcraft in Four African Societies: An Essay in Comparison". American Anthropologist 54 (1): 18-29.

Pype, Katrien. 2011. "Confession cum Deliverance:In/Dividuality of the Subject Among Kinshasa's Born-Again Christians". Journal of Religion in Africa 41 (3): 280-310.

Rio, Knut. 2010. "Handling Sorcery in a State System of Law: Magic, Violence and Kastom in Vanuatu". Oceania 80 (2): 182-197.

Sanders, Todd. 2008. Beyond Bodies: Rain-making and Sense-making in Tanzania. Toronto: University of Toronto Press.

Schram, Ryan. 2010. "Witches' Wealth: Witchcraft, Confession, and Christianity in Auhelawa, Papua New Guinea". Journal of the Royal Anthropological Institute 16 (4): 726-742.

Stephen, Michele. 1987. "Contrasting Images of Power". In Sorcerer and Witch in Melanesia, ed. M. Stephen, 249-304. Melbourne: Melbourne University Press. 
Tambiah, Stanley J. 1983. “On flying Witches and Flying Canoes: The Coding of Male and Female values". In The Kula: New Perspectives on Massim Exchange, eds. J.W. Leach, and E.R. Leach. Cambridge: Cambridge University Press.

Taylor, John P. 2015. "Sorcery and the Moral Economy of Agency: An Ethnographic Account". Oceania 85 (1): 38-50.

Weiner, Annette. 1976. Women of Value, Men of Renown: New perspectives in Trobriand exchange. Austin: University of Texas Press.

Zelenietz, Marty. 1981. "Sorcery and Social Change: An Introduction". Social Analysis 8: 3-14.

\section{Author Biography}

Michelle MacCarthy is an Assistant Professor in the Department of Anthropology at Saint Mary's University in Halifax, Canada. She was previously a Postdoctoral Fellow in the Department of Social Anthropology at the University of Bergen (where she undertook the research and writing of the chapter in this book), and where she was a contributor to Annelin Eriksen's Norwegian Research Councilfunded project on gender and Pentecostalism in Africa and Melanesia. She completed her PhD at the University of Auckland in 2012. Her monograph, entitled Making the Modern Primitive: Cultural Tourism in the Trobriand Islands (2016), examines tropes of primitivity and authenticity and mechanisms of cultural commoditization. She recently co-edited (with Annelin Eriksen) a special issue of The Australian Journal of Anthropology on Gender and Pentecostalism in Melanesia (August 2016).

Open Access This chapter is licensed under the terms of the Creative Commons Attribution 4.0 International License (http://creativecommons.org/licenses/by/4.0/), which permits use, sharing, adaptation, distribution and reproduction in any medium or format, as long as you give appropriate credit to the original author(s) and the source, provide a link to the Creative Commons license and indicate if changes were made.

The images or other third party material in this chapter are included in the chapter Creative Commons license, unless indicated otherwise in a credit line to the material. If material is not included in the chapter Creative Commons license and your intended use is not permitted by statutory regulation or exceeds the permitted use, you will need to obtain permission directly from the copyright holder.

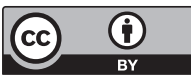

